大腸癌術後の縫合不全の危険因子ならびに予防対策

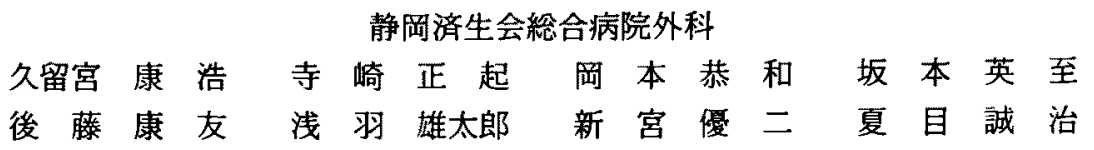

大腸癌術後の最も危険な合併症の一つである縫合不全について，その病態と治療向上 に関連する因子を明らかにする目的で，過去12年間に当院で大腸潞に対し待期および緊 急手術を含め切除を行った675例について retrospectiveに検討した。またイレウスと縫 合不全の関連，特に逆行性イレウス管が縫合不全の予防に有用か否かについて検討を加 えた、桻合不全は47例（7.0\%)にみられた，男性，術前イレウス，下部直腸癌，リンパ 節転移陽性は縫合不全の危険因子であった。保存的に治療した34例の繾合不全発症日と 経口摄取開始までの日数との間には有意な負の相関があった $(p<0.001)$.47例中再手術 は8例であったが、再手術後の経過は全例良好であった。縫合不全症例47例のうち在院 死亡は 5 例 $\left(10.6^{\circ}{ }_{0}\right)$ で, 縫合不全がない症例（在院死亡, $1.9^{\circ}{ }_{0}$ ) より有意に死亡率が 高かった.イレウスで発症した大晹癌に対して逆行性イレウス管を插入することにより 緊急手術を減少させ，かつ縫合不全の発症率も減少させることができた。

索引用語：大腸癌, 縫合不全、イレウス, 腸管隇压法

\section{緒言}

大腸癌術後の縫合不全は重大な術後合併症の一つで あり,一旦発症したら致命的となりうる ${ }^{122}$. その発症 率は3.2〜24.4\%と報告されているが37-8), その発症に 対し予防策を論じる報告はほとんどない3．そこでこ の病態と治療向上に関連する因子を明らかにするため 当院で経験した大腸癌衍後の縫合不全症例につき検討 した.

\section{対象および方法}

1989年 1 月から 2000 年 12 月まで過去12年間に当院て 大腸癌に対し待期的および緊急的手術を行った症例を 対象とした，そのうち腹会陰式直腸切断潃，人工肛門 造設などの腹腔内に消化管吻合のない手術を行った 120例と直死 3 例を除いた675例について retrospectiveに険討した。縫合不全の定義は臨床上，明らかな 便汁あるいは腸液の漏出を認めるか, 画像診断で瘦孔 と腸管との交通が明らかなものとし，䋖合不全発症日 の定義㹥手術から縫合不全発症までの期間とし，経口

2002 年 3 月 7 日受付 2002 年10月21日採用 〈所風施設住所〉

厂 422-8527 静岡市小鹿 $1-1-1$
搨取開始日の定義は縫合不全発症から経口搨取開始ま での期間とした．また大腸癌イレウスの定義を自覚症 状ならびに腹部単純 X線検查などの他覚所見でイレウ スと診断されたものとした，当院でこの大腸癌イレ ウスに対し1994年 8 月より逆行性イレウス管の乗入を 行い始め91, 1995年より直腸癌, S 状結腸癌のみならず 横行結腸癌, 上行結腸癌によるイレウスに対しても積 極的にこの方法を行っている。また，緊急例に对して も可及的に一期的に吻合することを基本方針としてい るため、これを行うための準備期間を含む前半の 6 年 間 (以後, 前期) と第一選択としたその後の 6 年間 (以 後, 後期) でイレウスと縫合不全の関連, 特に逆行性 イレゥス管の有用性につき検討を加えた，有意差検定 はStudent $\mathrm{t}$ 検定と $\chi^{2}$ 検定で行った。また生存曲線は Kaplan-Meier 法を用いて算出し, log-rank 娭定て 2

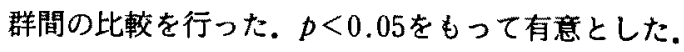

\section{結 果}

\section{1. 繾合不全発生率}

縫合不全は675例中47例，7.0\%にみられた。部直 腸癌例では縫合不全の割合が有意に高かった（表 1 ）。 また男性, 術前イレウス例、リンパ節転移例もその割 合が有意に高かったが, 癌の stage からみた進行度と 
表 1 癌の局在と繾合不全

\begin{tabular}{|c|c|c|c|c|}
\hline \multirow[t]{2}{*}{ 湌の局在 } & \multicolumn{2}{|c|}{ 硢合不全 } & \multicolumn{2}{|r|}{ 䋖合不全率 } \\
\hline & あり & なL & & \\
\hline$C+A$ & 8 & 147 & $5.2 \%$ & \\
\hline$T$ & 5 & 40 & $11.1 \%$ & \\
\hline$D+S$ & 5 & 224 & $2.2 \%$ & 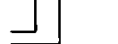 \\
\hline Rs & 7 & 77 & $8.1^{\circ} \mathrm{o}$ & $\overline{\mathrm{NS}}$ \\
\hline $\mathrm{Ra}$ & 13 & 92 & $12.3^{\circ} \mathrm{o}$ & $p=0.003$ \\
\hline $\mathrm{Rb}$ & 9 & 48 & $15.8^{\circ} \mathrm{o}$ & $p=0.002$ \\
\hline
\end{tabular}

$C$ : cecum, $A$ : ascending, $T$ : transverse, $D$ : descending, $\mathrm{S}:$ sigmoid

表 2 椠合不全の有無による比较

\begin{tabular}{|c|c|c|c|c|}
\hline 維合不全 & & $\begin{array}{c}\text { あり } \\
n=47\end{array}$ & $\begin{array}{c}\text { なし } \\
\mathrm{n}=628\end{array}$ & \\
\hline 年齔 (歳)・ & & $65.7 \pm 10.8$ & $65.9 \pm 12.0$ & NS \\
\hline 男女比 & & $36: 11$ & $363: 265$ & $p<0.05$ \\
\hline \multirow[t]{2}{*}{ 術前イレウス } & あり & 16 & 74 & $p<0.0001$ \\
\hline & なし & 31 & 554 & \\
\hline \multirow[t]{6}{*}{ 深達度 } & $\mathrm{m}$ & 0 & 21 & \multirow{6}{*}{ NS } \\
\hline & $\mathrm{sm}$ & 4 & 84 & \\
\hline & $\mathrm{mp}$ & 6 & 57 & \\
\hline & ss, al & 9 & 207 & \\
\hline & se, a2 & 23 & 228 & \\
\hline & si, a3 & 5 & 31 & \\
\hline \multirow[t]{6}{*}{ リンパ節転移 } & no & 19 & 354 & \multirow{6}{*}{$p<0.05$} \\
\hline & $\mathrm{nl}$ & 17 & 158 & \\
\hline & $\mathrm{n} 2$ & 6 & 76 & \\
\hline & $\mathrm{n} 3$ & 5 & 22 & \\
\hline & $\mathrm{n} 4$ & 0 & 8 & \\
\hline & 不明 & 0 & 10 & \\
\hline \multirow[t]{4}{*}{ 組辏型 } & well & 4 & 92 & \multirow{4}{*}{ NS } \\
\hline & $\bmod$ & 36 & $4 \times 2$ & \\
\hline & por & 4 & 26 & \\
\hline & muc & 3 & $2 x$ & \\
\hline \multirow[t]{7}{*}{ stage } & 0 & 0 & 21 & \multirow{7}{*}{ NS } \\
\hline & 1 & $x$ & 115 & \\
\hline & 2 & 11 & 188 & \\
\hline & $3 a$ & 13 & 154 & \\
\hline & $3 \mathrm{~b}$ & $x$ & $x_{0}$ & \\
\hline & 4 & 7 & 61 & \\
\hline & 不明 & 0 & 9 & \\
\hline
\end{tabular}

縫合不全との関連は認められなかった（表 2).

\section{2、繾合不全と吻合部位，吻合方法との関連}

下部直腸に縫合不全が多いことを反映して，結腸直 腸吻合で多い傾向がみられた(表 3)。吻合方法では器 械吻合で有意に多かった(表 4)。これは直晹癌の手術 の95\%で器械吻合が行われている結果であると考えら
表 3 吻合部位と緒合不全

\begin{tabular}{|c|c|c|c|c|}
\hline \multirow[t]{2}{*}{ 吻合部位 } & \multicolumn{2}{|c|}{ 綪合不全 } & \multirow{2}{*}{\multicolumn{2}{|c|}{ 綎合不全染 }} \\
\hline & あり & なし & & \\
\hline 回腸結得吻合 & 8 & 135 & $5.6 \%$ & \\
\hline 結腸結腸吻合 & 10 & 155 & $5.5 \%-$ & NS \\
\hline 結渴淔腈吻合 & 28 & 335 & $8.0 \%-$ & \\
\hline 直腸㨁腸吻合 & 1 & 3 & $25 \%$ & \\
\hline
\end{tabular}

表 4 吻合方法と維合不全

\begin{tabular}{|c|c|c|c|c|}
\hline \multirow[t]{2}{*}{ 吻合方法 } & \multicolumn{2}{|c|}{ 檤合不全 } & \multicolumn{2}{|c|}{ 䋖合不全率 } \\
\hline & あり & なし & & \\
\hline layer to layer" & 6 & 111 & $5.1 \%$ & \\
\hline Gambee & 13 & 294 & $4.2 \% \quad]$ & $p<0.001$ \\
\hline 器械㔚合 & 28 & 223 & $11.2 \%$ & \\
\hline
\end{tabular}

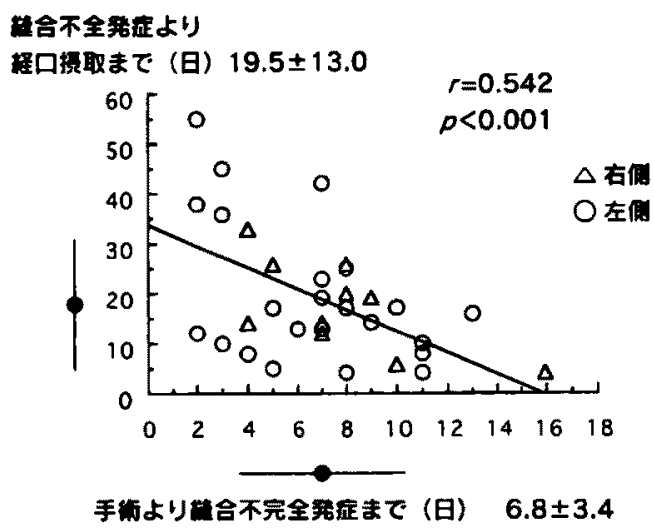

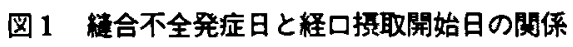

れた。な技直腸癌手術246例中，器械吻合の縫合不全は 27/234例（11.5\%)，手縫いによる縫合不全は $2 / 12$ 例 (16.7\%) で，手繾いによる縫合不全率のほうが高い 結果であったが，統計学的有意差はなかった。

\section{3. 䋖合不全発症日と経口摄取開始日の関係}

縫合不全47例中，死亡 5 例と再手衔 8 例を除く，保

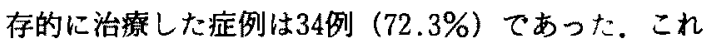
ら保存的に治療した症例の縫合不全発症日の平均は 6.8日であった。また縫合不全発症日と経口提取開始ま での日数との間には有意な負の相関があった（ $p<$ 0.001 )（国 1 ).

\section{4. 綎合不全と再手術, 在院死亡との関连}

再手術は47例中 8 例であり 7 例が左側結腸癌の症例 であった，再手術に伴う死亡例はなかった。再手術に 
表 5 䋖合不全と再手術例

\begin{tabular}{|c|c|c|c|c|c|c|}
\hline 年齢 & 性 & 部位 & 手衔 & 発症(日) & 発症状況 & 再手術 \\
\hline 66 & M & S & S切 & 8 & ドレーン抜去後腹腔内脿湶 & 人工肛聞造設 \\
\hline 68 & M & $\mathrm{S}$ & $S(t]$ & 11 & ドレーン菠去後腹腔内滕踢 & 人工肛門造設 \\
\hline 62 & M & $\mathrm{Ra}$ & LAR & 6 & 腹膜炎 & 人工肛門造設 \\
\hline 65 & M & D & D切 & 11 & 腹膜炎 & 人工肛門造設 \\
\hline 60 & $M$ & $\mathrm{Rb}$ & LAR & 6 & 腹膜炎 & 人工肛門造設 \\
\hline 61 & M & A & 右半 & 2 & 47日，保存的に治湼せず & 端々吻合 (再) \\
\hline 57 & $\mathrm{~F}$ & $\mathrm{Ra}$ & LAR & 2 & 35日，保存的に治腹せず & 人工肛門造設 \\
\hline 74 & $\mathrm{M}$ & $\mathrm{Rb}$ & LAR & 2 & 16日, 保存的に治虑せず & 人工肛門造設 \\
\hline
\end{tabular}

表 6 䌯合不全と在院死亡例（直死 3 例を除く）

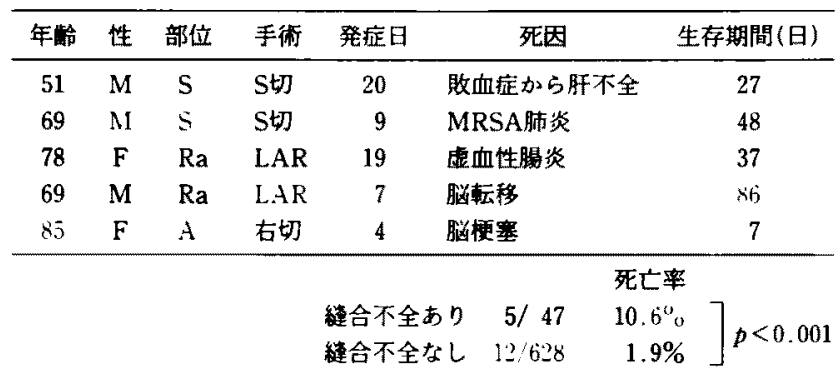
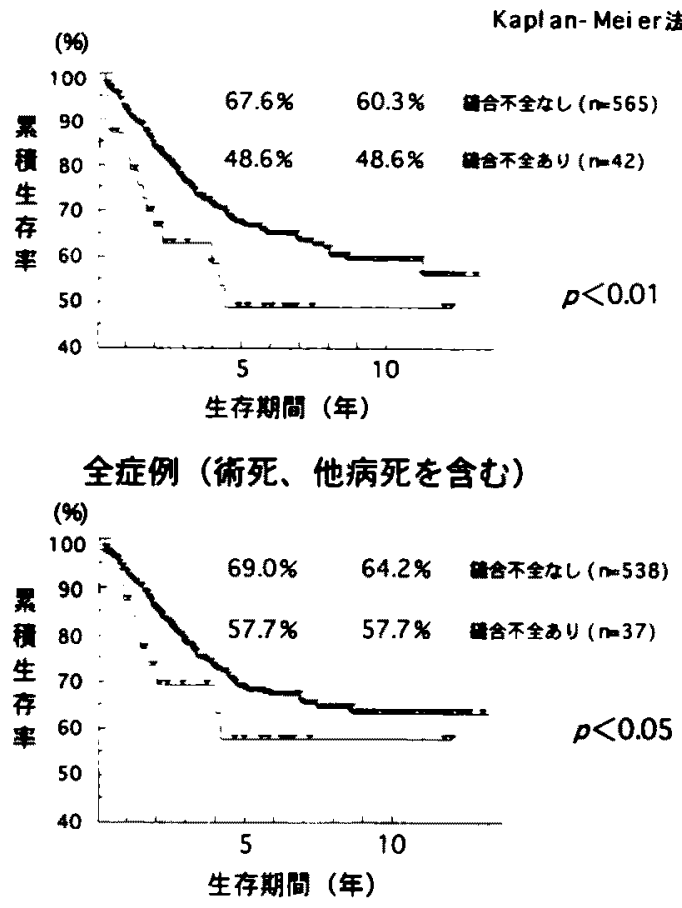

原病死のみ（術死、他病死を除く）

图 2 絙合不全の有無に上る術後生存曲線
表 7 イレウス症例107例

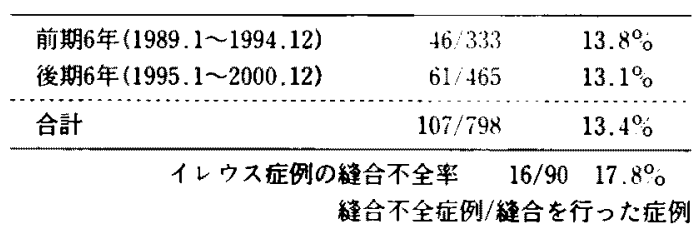

いたるパターンは 3 通りであった(表 5 )。再手術後の 経過は全例良好であった。縫合不全症例47例のうち， 在院死亡は 5 例 $\left(10.6^{\circ} \%\right)$ で，4例が左側結腸癌の症 例でった，縫合不全症例は縫合不全がない症例（在 院死亡， $1.9 \%$ ）に比べ有意に死亡率が高かった $(p<$ 0.001) (表6).

\section{5. 繾合不全例の長期予後}

長期予後が明らかな縫合不全症例42例と繸合不全の ない565例を比較すると，5年，10年生存率はそれぞれ $48.6,48.6 \%$ 対 $67.6,60.3 \%$ で縫合不全症例の予後が 有意に不良であった（図 $2 \mathrm{~A}$ )。さらに術死，他病死を 除いた原病死のみの 5 年, 10 年生存率はそれぞれ 57.7 , $57.7 \%$ 対 $69.0,64.2 \%$ で縫合不全症例の予後が有意に 不良であった（図 2 B).

\section{$\frac{\mathrm{A}}{\mathrm{B}} \quad 6$. 綎合不全とイレウスとの関連}

観察期間中大腸癌イレウス症例は107例で全体の 
表 8 イレウス症例に対する逆行性イレウス管挿入の成績

\begin{tabular}{|c|c|c|c|c|c|c|}
\hline & \multicolumn{3}{|c|}{$\begin{array}{c}\text { 前期 } \\
n=46\end{array}$} & \multicolumn{3}{|c|}{$\begin{array}{c}\text { 後期 } \\
\mathrm{n}=61\end{array}$} \\
\hline & 成功 & 不成功 & 施行せず & 成功 & 不成功 & 施行せず \\
\hline A & & & 3 & 1 & 1 & 7 \\
\hline $\mathrm{T}$ & 1 & 1 & 5 & 3 & 2 & 1 \\
\hline D & & 1 & 1 & 7 & 1 & 2 \\
\hline $\mathrm{s}$ & 2 & 4 & 13 & 20 & 2 & 4 \\
\hline $\mathbf{R}$ & 3 & & 12 & 8 & 1 & 1 \\
\hline 合貄 & 6 & 6 & 34 & 39 & 7 & 15 \\
\hline 成功率 & \multicolumn{2}{|c|}{$50.0^{\mathrm{o}} \mathrm{o}$} & \multicolumn{4}{|c|}{$84.8 \%$} \\
\hline
\end{tabular}

$A$ : ascending, $T:$ transverse, $D$ : descending, $S$ : sigmoid, $R$ : rectum

表 9 イレウス症例に対する strategy と繾合不全

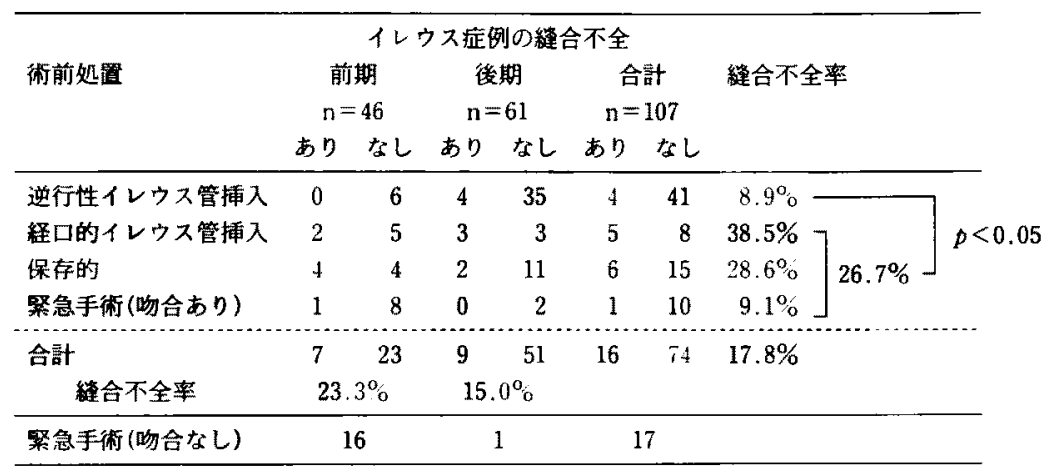

$13.4 \%$ に相当した. 前期 6 年, 後期 6 年でイレウス症 例の割合には差はなかった（表子）。逆行性イレウス管 の挿入の成功率は前期 $50 \%$, 後期 $85 \%$ であった(表 8 )。 イレウス症例の縫合不全率は $17.8 \%$ と高かった，逆行 性イレウス管を㨉入した症例は挿入しなかった症例に 比べその発症率は有意に低加た $\left(8.9 \%\right.$ 対 $\left.26.7^{\circ}{ }^{\circ}\right)$. イレウスで発症した大腸癌に对して逆行性イレウス管 の挿入を積極的に行い始め大後期で、前期に比へ緊 急手術を減少させ，一期的な吻合が可能な症例数の增 加がみられ，かつ縫合不全の発症率も隇少していた $(23.3 \%$ 対 $15.0 \%)$ （表 9$)$.

\section{考察}

インフォームドコンセントが重要視される今日, 大 腸癌術後の縫合不全の病態を明らかにし，術前加適 切に病態と治療上の問題点を患者に説明することが必 要である。縫合不全は致命的となりうる重大な合併症 であるにも関わらず，本邦においては縫合不全に関す る論文は数少な(い) ${ }^{3)-510}$.これらのことから, 今回の検 討を行った。
縫合不全注675例中47例，7.0\%にみられた。男性， 術前イレウス例，下部直腸癌例，リンパ節転移例は縫 合不全の危険因子であった，䋖合不全の最大の原因と しては癌による狭唯, 浮腫, 異常な細菌増殖などのイ レウス準供状態で一期的吻合を行った場合であるとい われる ${ }^{10)}$ ．また男性の下部直腸癌に縫合不全が多く認 められた，この原因としては，低位前方切除では吻合 部が骨盤内の後腹膜にあり，特に男性では狭い視野で の手術操作の困難な場合があることと, 前処置での䔬 便の量を十分に減少てきない場合があることが原因で あるといわれている45). 加われの症例においても同 様の結果が得られ，手術のみならず術前からの管理の 重要性が再認識された。また今回の検討でリンバ節転 移例て縫合不全の発症が多かったが、おそらくリンパ 節転移陽性例では主要血管のより広籍な郭清を行うた め，その結果として吻合部位への血流がそしくなり縫 合不全の発症が増加した可能性が考えられた。

縫合不全の発症日の平均は6.8日で, ドレーン早期拔 去後の膿痬形成といった症例も経験したことより,一 
般的に大腸癌術後のドレーン抜去の時期は術後 8 日以 降が望ましいと考えられた。

保存的に治療した症例は34例（72.3\%）であった。 これら保存的に治療した症例の縫合不全発症日と経口 摂取開始まての日数との間には有意な負の相関があっ た。つまり術後早期の発症ほど治瘾が遷延する。また われわれの症例では再手術後の経過は全例良好であっ た. 一方，縫合不全症例の死亡率は $25 \%$ から $35 \%$ と報 告され ${ }^{11)}$, 今回の検討でも縫合不全のあるものはない ものに比べ死亡率は $10.6 \%$ と有意に高かった，その病 態と治療体系は大腸穿孔症例の保存的治療にも等し い. 一旦発症したら，特に左側結腸癌症例において致 命的となる ${ }^{122}$.これらのことより早期発症例では早期 の再手街を考慮に入れた厳重な管理が必要であると考 えられた。

縫合不全症例の長期予後は縫合不全のないものに比 べ有意に不良であった。䋖合不全症例が直腸癌に多い こと，またリンパ節転移例が多いことから単純に縫合 不全のないものとの比較は困難と考えられるが, 癌の stage からみた進行度と縫合不全の有無との間に有意 差がなかったことを考慮するとこの生存率の差は無視 できないものと考える. Docherty $ら^{8)}$ も大腸癌におけ る縫合不全症例の局所再発率が高く，その長期予後が 不良であることを指摘している．彼らは腸管内から漏 出した腫瘍細胞が局所再発とその後の転移の形成に関 与する可能性を示唆しているが，今回の検討でも彼ら と同様の結果が得られた。

イレウスは縫合不全の最大の原因ともいわれる が10), われわれの検討でもイレウス症例の綘合不全率 は17.8\%と高かった。しかし逆行性イレウス管は有意 にその発症率を減少させた。特に逆行性イレウス管の 括入を積極的に行い始めた後期 6 年では, 前期 6 年に 比へ緊急手術を減少させ，かつ縫合不全の発症率も減 少した，以前われわれ蛙逆行性イレウス管の有用性と して，1. 腸管の浮腫, 㹡張が軽減され, 一期的吻合 が可能，2. 全身状態の改善と術後合併症の予防効果, 3. 口側腸管の造影により, 病変の範囲, 質的診断に 有用，4. 十分な術前検查後の安全な待期的根治手術, 5.イレウスの改善と自覚症状の速やかな改善，など を指摘してきたが9), 今回, この逆行性イレウス管挿入 が縫合不全の発症の予防策としても有用であることが 明らかとなった。

特に頻度の高い直腸癌術後の縫合不全においては直 腸の長期的な貯蔵機能低下，運動機能低下，便意切迫
性の闌値の低下をきたし，患者のQOL を著しく損ね ることも知られている 生存率にも影響すると考えられる縫合不全に対する予 防として，慎重な手術操作および周術期管理の向上が 不可欠である。しかし不幸にも一旦発症した埸合，迅 速に病態を把握し早期に適切な処置を行うことが必要 である。

\section{文 献}

1) Schrock TR, Deveney CW, Dunphy JE: Factor contributing to leakage of colonic anastomoses. Ann Surg $177: 513-518,1973$

2) Heald RJ, Karanjia ND: Results of radical surgery for rectal cancer. World J Surg $16: 848$ $-857,1992$

3）白井芳則，小野正人，新井竜夫他：結腸蹈術後吻 合部障害の検討.日臨外医会誌 $57: 2629-2633$, 1996

4）永瀨浩喜, 長尾和治, 松田正和他：大腸癌術後の 創感染拉よひ縫合不全についての臨床的検討．日 臨外医会誌 $51: 472-477,1990$

5）長山正義，烅野匡有，池原照幸他：大腸癌手術に おける縫合不全の検討．日臨外医会誌 $48: 1992$ $-1996,1987$

6) Fielding LP, Stewart-Brown $S$, Blesovsky $L$, et al : Anastomotic integrity after operations for large-bowel cancer : a multicentre study. $\mathrm{Br}$ Med J 281 : 411-414, 1980

7) Tuson JR, Everett WG : A retrospective study of colostomies, leaks and strictures after color. ectal anastomosis. Int J Colorectal Dis $5: 44-$ 48,1990

8) Docherty JG, McGregor JR, Akyol AM, et al: Comparison of manually constructed and stapled anastomoses in colorectal surgery. Ann Surg $221: 176-184,1995$

9）李 政秀, 寺崎正起，清水泰博他：経肛門的隇圧 により一期的に手術しえた S 状結腸癌の 3 例。静 岡済生会総合病医誌 $12: 35-38,1995$

10）加藤紘之, 由辺橽三：術後合併症-縫合不全, 日臨 $47: 883-888,1989$

11) Merad F, Hay JM, Fingerhut A, et al : Omentoplasty in the prevention of anastomotic leakage after colonic or rectal resection : a prospective randomized study in 712 patients. French 
Associations for Surgical Research. Ann Surg $227: 179-186,1989$

12) Hallbook $O$, Sjodahl $R:$ Anastomotic leakage and functional outcome after anterior resection of the rectum. Br J Surg 83:60-62, 1996

\title{
A STUDY OF RISK FACTORS AND THE PREVENTION OF ANASTOMOTIC LEAKAGE AFTER SURGERY FOR COLORECTAL CANCER
}

\author{
Yasuhiro KURLMIIYA. Masaki TERASAKI, Yasukatsu OKAMOTO, Eiji SAKAMOTO, \\ Yasutomo GOTO, lutaro ASABA, Yuji SHINGU and Seiji NATSUME \\ Department of Surgery, Shizuoka Saiseikai General Hospital
}

To clarify factors improving the condition of anastomotic leakage that is one of the severe postoperative complications of colorectal cancer, we retrospectively examined consecutive 675 patients undergoing ordinary or emergency operation for colorectal cancer at this hospital for the past 12 years. In this study, we also examined the correlation between ileus and anastomotic leakage, particularly whether preoperative insertion of a retrograde decompression ileus tube was useful for the prevention of anastomotic leakage. Anastomotic leakage occurred in +7 patients (7.0\%). Nale, preoperative ileus, cancer of the lower part of rectum and lymph node metastasis were risk factors of anastomotic leakage. Of 34 patients treated conservatively, there was a significantly negative correlation $(p<0.001)$ between the day of the onset of anastomotic leakage and the day of beginning of oral intake. Of the 47 patients experienced anastomotic leakage, eight patients underwent reoperation, but after the reoperation, all patients had a good postoperative course. Five out of the 47 patients with anastomotic leakage (10.6\%) died in the hospital. The mortality rate in the patients with anastomotic leakage was significantly higher than those without episodes of anastomotic leakage (hospital death $1.9 \%$ ). We were able to decrease the incidence of anastomotic leakage as well as emergency operations for patients with colorectal cancer presented with ileus, by inserting a retrograde decompression ileus tube. 